\title{
REKONSTRUKSI BENTUK ARSITEKTUR CANDI PADANG ROCO DI KABUPATEN DHARMASRAYA SUMATERA BARAT
}

\author{
Ardiansyah $^{1,{ }^{\star}}$, Ricky Ravsyan ${ }^{1}$, Ria Dwiputri ${ }^{1}$, \\ ${ }^{1}$ Program Studi Arsitektur, Fakultas Teknik, Universitas Sriwijaya, \\ Jl Palembang -Prabumulih Km 32, 30862 \\ *ardiansyahst01@gmail.com
}

\begin{abstract}
Abstrak. Penelitian rekonstruksi bentuk Candi di Sumatera perlu dilakukan dikarenakan Candi di Sumatera umumnya hanya tersisa bagian kaki, sehingga penelitian mengenai langgam dan terkait budaya sulit dilakukan. Selain itu kajian pemaknaan bentuk dan perumusan langgam arsitektur candi perlu dilakukan kajian morfologi terlebih dahulu. Permasalahan yang dijumpai pada situs percandian di Sumatera adalah tidak semua candi di Sumatera memiliki bentuk yang utuh melainkan mayoritas hanya menyisakan bagian dasar candi dan paling lengkap hanya badan candi, hal ini apabila dibiarkan maka masalah ini akan tetap mengambang tanpa ada solusi ke depan. Berdasarkan permasalahan tersebut diperlukan kajian tafsiran bentuk candi secara utuh. Dari beberapa penelitian umumnya menggunakan metode komparasi dengan melihat bangunan-bangunan candi di Indonesia akan tetapi metode urutan rekonstruksi bentuk tidak begitu rinci, di dalam penelitian ini metode yang digunakan adalah metode kualitatif dan bersifat penelitian lapangan. Adapun analisis data yang dilakukan menggunakan analisis morfologi dan komparasi, data hasil pengukuran candi Padang Roco dirumuskan angka perbandingannya. Berdasarkan hasil rekonstruksi ditemukan bahwa bentuk Candi Padang Roco memiliki gaya arsitektur yang berbeda dari candi di Indonesia pada umumnya mulai dari bentuk punden berundak seperti tipe candi di Indo-Cina. Bentuk candi ini juga serupa dengan keberadaan struktur kuno yang berbentuk punden berundak yang ditemukan di Lampung dan memiliki analogi dengan perabotan tradisional di Palembang juga serupa dengan punden berundak.
\end{abstract}

Kata Kunci : Rekonstruksi, Bentuk, Proporsi, Candi

ABSTRACT. Research on the reconstruction of temple form in Sumatera needs to be done because the temples in Sumatera generally only left with the base of the temple, so research on culture and culture-related is difficult. Besides that, the study of the meaning of the form and formulation of the temple architectural style needs to be carried out morphological study first. The problem encountered in the ensemble site in Sumatera is that not all of them have a complete form, but the majority only leaves the leg and most complete only the body parts of the temple. This problem will remain floating without any future solutions. Based on these problems, the researchers tried to begin by enlightening the study of how the interpretation of the temple form, which left the foot of the temple became the appearance of the temple as a whole. From several studies generally using the comparative method by looking at temple buildings in Indonesia but the purpose of explanation of the order of the reconstruction process is not very detailed, in this study the method used is qualitative and is field research. As for the data analysis carried out using morphological and comparative analysis, the data from the measurement of Padang Roco temple were compared. Based on the result of the reconstruction it was found that the shape of the Padang Roco temple had a different architectural style from the temples in Indonesia, in general, ranging from the form of Punden terraces such as the type of temple in Indo-China. The shape of the temple is also similar to the existence of ancient structure in the form of Punden terrace found in Lampung and have an analogy with traditional furniture in Palembang which is also identical to Punden form.

Keywords : Reconstruction, Form, Proportion, Candi

\section{PENDAHULUAN}

Indonesia merupakan Negara yang memiliki perjalanan sejarah yang panjang dimana terdapat beberapa peradaban yang berkembang yang menghasilkan kerajaan kerajaan besar di nusantara. Salah satu kerajaan yang pernah berkembang dari abad 7 sampai 14 adalah kerajaan Sriwijaya yang memiliki hegemoni kekuasaan utama di Sumatera dan memegang kendali perdagangan laut dengan kekuatan maritim yang kuat. Setiap kebudayaan akan menghasilkan nilai nilai yang ujungnya meninggalkan artefak-artefak sebagai buah dari peradaban, salah satu bentuk artefak 
adalah bangunan Candi. Kajian mengenai Sriwijaya umumnya didasari kajian antropologi dan sejarah sedangkan kaitan artefak arsitektural khususnya candi jarang dilakukan hal ini dikarenakan belum banyak para ahli atau peneliti mencoba menarik benang merah terhadap candi-candi di Sumatera. Selain itu keberadaan candi di Sumatera umumnya tidak memiliki bentuk yang utuh hanya sebagian kecil yang sudah dilakukan pemugaran secara utuh sedangkan $90 \%$ masih memiliki bentuk yang kurang utuh mayoritas hanya menyisakan bagian kaki candi bahkan hanya pondasi saja. Di Sumatera setidaknya memiliki lima kawasan situs percandian yaitu Bumiayu di Sumatera Selatan, Muaro Jambi, Muaro Takus di Kampar Riau, Padang Roco di Dharmasraya Sumatera Barat dan Situs Padang Lawas di Sumatera Utara. Dari kelima situs hanya dua situs yang umumnya memiliki bentuk yang cukup utuh yaitu Situs Candi Muaro Takus dan Padang Lawas.

Minimnya petunjuk bentuk candi secara utuh juga secara tidak langsung membuat semangat restorasi bangunan candi di Sumatera agak sulit berkembang karena kondisi situs dilapangan sangat sederhana karena hanya menyisakan bagian dasar saja sehingga kurang menarik minat wisatawan. Berdasarkan pengamatan dilapangan proses pemugaran candi sulit dilakukan hal ini dikarenakan arkeologi sulit membaca petunjuk dari sisa reruntuhan yang ada sehingga mereka hanya mampu merekonstruksi bentuk berdasarkan kemungkinan terbesar yang bisa dipertanggungjawabkan secara arkeologis, sehingga tidak mengherankan banyak pemugaran candi yang hanya berakhir pada kaki bangunan saja. Kegiatan wisata maupun kegiatan rekonstruksi bentuk candi diperlukan dukungan kajian terkait penafsiran bentuk candi.

Penafsiran bentuk candi memang sulit diterima begitu saja oleh masyarakat ilmiah dan pemerintah melalui balai arkeologi akan tetapi kegiatan penafisran bentuk ini memberikan semangat yang bisa meningkatkan kinerja kegiatan rekonstruksi candi karena umumnya arkeolog ada atau pun tidak ada kajian mereka akan terus melakukan rekonstruksi bangunan candi sehingga data teori yang menjadi pedoman mereka sangat sedikit dan hasil pemugaran tentu saja meninggalkan keraguan karena kurang alternatif di dalam berfikir. Peneliti Belanda seperti schnitger pernah membuat kajian tafsiran bentuk candi Muaro Jambi begitu juga dengan Soekmono pernah membuat tafsiran bentuk Candi Tinggi dan
Gumpung pada situs Muaro Jambi akan tetapi pendekatan bentuk yang dilakukan masih bersifat umum belum detail tahapan rekonstruksinya, akan tetapi hasil kajian itu cukup memberikan warna dan membuka ruang kajian penelitian terkait penafsiran bentuk candi. Berdasarkan penelitian yang pernah dilakukan peneliti terhadap Candi di Sumatera, umumnya candi memiliki konsep bentuk morfologi yang relatif sama dan apabila melihat pedoman dan patokan pembangunan candi yang ada dalam vaastu shastra dan hasil pembacaan relief bentuk candi pada panil dinding candi Borobudur sangat memungkinkan melakukan reka bentuk candi sumatera secara utuh.

Salah satu situs di Sumatera adalah Situs Candi padang Roco situs ini memiliki 3 candi pada satu lokasi dan satu candi yang berada tidak jauh dari kelompok candi akan tetapi candi Padang Roco hanya meninggalkan bagian dasar candi sehingga kurang interaktif untuk dipromosikan sebagai objek wisata candi ini terlatak di Kabupaten Dharmasraya Kecamatan Sungai dare Sumatera Barat. Melihat tata spasial didalam kompleks percandian Padang Roco memiliki bentuk yang tidak umum dari pola candi di Nusantara dimana pada kasus Candi 01 memiliki empat orientasi bangunan yang sangat jarang ditemukan di Indonesia umumnya terdapat di Angkor Indocina selain itu Candi 03 berupa candi perwara juga membelakangi candi 01 dimana umumnya orientasi candi kearah candi utama sedangkan candi 02 memiliki bentuk denah yang sama dengan candi Bungsu di Muaro Takus.

Penelitian ini mempelajari bentuk arsitektur dari Candi Padang Roco dimana pada kajian ini diharapkan mendapatkan satu rangkaian petunjuk keterkaitan bentuk antara candi lainnya di Sumatera. umumnya peneliti jarang meneliti bagaimana menafsirkan bentuk candi yang belum terbentuk secara total sehingga masyarakat umum masih bertanya bagaimana bentuk tampilan tersebut sebelum hancur. Hasil dari kajian sangat berguna sebagai informasi bagi dunia pendidikan dan penelitian selanjutnya mengenai langgam arsitektur Candi dan bagi pemerintah bisa menjadi dasar dan pengayaan referensi didalam kegiatan konservasi candi. Metode penafsiran bentuk bangunan sangat mungkin dilakukan sebagai contoh adalah kegiatan rekonstruksi bentuk dibidang biologi seperti reka bentuk fosil tulang hewan atau manusia purba dan mencoba membangun rekonstruksi bentuk wajah maupun tubuh dari fosil tersebut. metode ini 
bisa digunakan untuk mencari bentuk arsitektural bangunan berdasarkan petunjuk sisa komponen bangunan dengan dasar kajian morfologi terkait tata letak, pola dan proporsi yang menyusun rangkaian bentuk sebuah bangunan. Dalam kajian rekonstruksi Candi Pada Roco peneliti memerlukan pendekatan teori terkait studi tipomorfologi, analogi bangunan candi yang terikat secara morfologis dan teori terkait proporsi bangunan candi seperti silpastra India dan kajian bentuk candi di Jawa.

Analogi banyak dikemukakan oleh para ahli dengan pendekatan masing masing akan tetapi tinjauan disini hanya mengutip teori yang sering dipakai didalam arsitektur sehingga tidak terlalu meluas penafsiranya. Menurut Chris Abel, analogi di dalam arsitektur digunakan seperti bahasa yang mempunyai fungsi [1]. Analogi selanjutnya dikemukakan oleh Broadbent dimana analogi disini merupakan proses pencarian bentuk. Broadbent membagi pendekatan bentuk ke dalam 4 kategori [2] ;

(a) Pragmatik : Pendekatan melalui tahap percobaan, trial and error. Penciptaan bentuk terjadi berawal dari material yang ada yang diolah menggunakan alat yang dimiliki dan disesuaikan dengan keadaan iklimnya.

(b) Ikonik yaitu Pendekatan melalui tradisi, kebiasaan yang telah umum dilakukan atau berdasarkan kesepakatan sosial. Dalam hal ini kondisi social dan budaya masyarakat setempat sangatlah berpengaruh.

(c) Analogik : Pendekatan analogi alam, atau segala sesuatu. Melalui proses analogi akan muncul bentuk visual baru berdasarkan bentuk visual yang telah dikenal sebelumnya .

(d) Kanonik/geometrik yang kemudian dikembangkan menjadi Sintaksis : Pendekatan sistem geometris, matematis, keteraturan, modul dsb. Yaitu digunakannya perbandingan Pythagoreans, proporsi Egyptian, geometri Plato dan sebagainya. Disini Broadbent menggunakan Analogi sebagai suatu mekanisme Synectics, yaitu proses untuk menterjemahkan analisa menjadi sintesa.

Selain pendekatan bentuk Broadbent membagi tiga tipe analogi meliputi ;

(1) Analogi Personal : Desainer menempatkan dirinya sebagai salah satu aspek dalam masalah desain.

(2) Analogi Langsung: Masalah desain dikaitkan dengan ilmu lainnya seperti seni, sains atau teknologi.
(3) Analogi Simbolik : Desainer mencoba menemukan inti dari arti khusus pada masalah desain, biasanya secara verbal.

Kajian analogi selanjutnya dikemukakan oleh Duerks [3] bahwa analogi berhubungan pada beberapa hal terutama pada fungsi atau posisi diantara dua benda yang tidak sama. Dua benda dikatakan sama jika mempunyai kesamaan dalam beberapa hal, maka keduanya akan mempunyai kesamaan pula pada hal lainnya. Pendapat yang dikemukan oleh Duerks hampir serupa dengan Broadbent akan tetapi didalam teorinya menambahkan analogi fantasi . Analogi fantasi adalah analogi yang mengibaratkan keadaan yang indah atau ideal untuk menciptakan .

Arsitektur identik dengan estetika dari sebuah karya. Estetika terbentuk dari komposisi dari berbagai pola dan elemen yang bisa dinilai dari visualnya. Untuk membuat sebuah rancangan yang mempunyai estetika tentunya perlu memperhatikan prinsip-prinsip perancangan. Ching menyebutkan terdapat tujuh prinsip-prinsip desain yang digunakan sebagai pedoman untuk menyusun elemenelemen desain menjadi pola-pola yang jelas. Prinsip-prinsip tersebut adalah proporsi, skala, keseimbangan, keserasian, kesatuan, ritme, dan penekanan, Salah satu prinsip desain yang paling mendasar adalah proporsi. Proporsi digunakan untuk membagi bidang atau lahan tertentu dengan perbandingan rasio yang ideal sehingga desain memiliki pembagian yang ideal baik untuk bagianbagian detailnya maupun keseluruhannya. Proporsi menyangkut tentang hubungan dari bagian satu dengan yang lainnya atau dengan keseluruhannya, atau bisa pula hubungan antara satu obyek dengan obyek lainnya [4]

Proporsi ditentukan oleh sebuah rasio dasar yang permanen dan digunakan sebagai penentu rasio berikutnya dalam sebuah obyek, seorang ahli matematika Yunani Kuno menyatakan bahwa rasio merujuk pada sebuah perbandingan kuantitatif dari dua benda yang serupa, sedangkan proporsi merujuk kepada kesetaraan masing-masing rasio tersebut. Proporsi dapat terbentuk dari hubungan antara bagian-bagian suatu elemen, hubungan antara elemen-elemen, serta hubungan antara elemen dan ruang/spasialnya [4]

Berkaitan dengan proporsi pada candi, berdasarkan pada hasil penemuan Atmadi, bahwa proporsi sebuah candi bisa ditentukan 
dengan membandingkan ukuran dari setiap bagian candi seperti perbandingan tinggi kaki (Tk) terhadap tinggi bangunan (T), perbandingan tinggi kaki (Tk), tinggi badan (Tb) dan tinggi atap (Ta), perbandingan lebar pintu (Lp) terhadap tinggi bangunan (T), perbandingan tinggi pintu (Tp) terhadap panjang dasar bagian kaki $(P)$, perbandingan lebar pintu (Lp). terhadap panjang bangunan $(P)$, serta perbandingan lebar pintu (Lp) terhadap tinggi pintu (Tp) [5]

Beberapa hasil temuan Atmadi yang akan dijadikan acuan dalam penelitian ini adalah sebagai berikut [5] : Perbandingan tinggi kaki (Tk) terhadap tinggi bangunan (T) adalah $1: 5$. Perbandingan tinggi kaki (Tk), tinggi badan (Tb) dan tinggi atap (Ta) adalah $4: 6: 9$. Perbandingan lebar pintu (Lp) terhadap tinggi bangunan $(\mathrm{T})$ adalah 1 : 10. Perbandingan tinggi pintu (Tp) terhadap panjang dasar bagian kaki $(\mathrm{P})$ adalah 3 : 8. Perbandingan lebar pintu (Lp) terhadap panjang bangunan (P) adalah $1: 8$. Perbandingan lebar pintu (LP) terhadap tinggi pintu (Tp) adalah $2: 5$. Didalam tulisannya Atmadi juga mereferensi aturan manasara Silphasastra akan tetapi didalam kajiannya membaca relief Borobudur penulis membaginya lagi kedalam lima kategori yaitu bangunan satu bilik, bangunan tiga bilik, bangunan bertingkat dua dengan enam bilik, bangunan tak berbilik, dan bangunan satu bilik dengan denah segi enam tanpa bilik pintu. Didalam penelitiannya Atmadi membagi bangunannya menjadi bangunan bertingkat dan tidak bertingkat, adapun bangunan tidak bertingkat terdiri dari ; bangunan 1 bilik dimana proporsi tinggi candi 1,5 x lebar kaki, bangunan tiga bilik memiliki tinggi $1 \times$ lebar kaki. Sedangkan bangunan bertingkat dua proporsi tinggi dan lebar meliputi; bangunan 3 bilik memiliki Tinggi 1 $1,75 \times$ lebar kaki dimana Tinggi kaki 0,21 tinggi total dan Tinggi atap $=0,45 \times$ tinggi total.

Tata cara pembangunan candi banyak dibahas dalam buku-buku tentang Hindu Architecture dan Indian Architecture. Salah satunya terdapat dalam Manasara-Silpasastra. Dalam Manasara-Silpasastra tidak hanya membahas candi saja, namun terdapat pula bahasan tentang tata cara membangun rumah serta langkah-langkah dalam menentukan site yang baik untuk setiap fungsi yang akan dibangun. Khususnya pada sistem proporsi, secara umum juga dijelaskan dalam ManasaraSilpasastra tentang dimensi bangunan berdasarkan variasi tingkatannya yang disebut dengan istilah bhumilamba-vidhana
Bhumilamba dalam Manasara diartikan sebagai ukuran panjang, lebar/tebal dan tinggi dari sebuah bangunan satu tingkat hingga dua belas tingkat.

Variasi bentuk dasar bangunan ada berupa persegi, oval, dan octagonal dan digunakan dalam setiap fungsi bangunan seperti pada vimana atau tempat suci, harmya atau istana, gopura atau gapura/pintu masuk, sala atau hall, mandapa atau pavilion, dan vesman atau rumah. Bangunan juga dibagi dalam empat kelas yaitu jati, chhanda, vikalpa/samkalpa, dan abhasa dimana keempat kelas ini saling berhubungan dan mempunyai perbedaan karakter dalam setiap bangunannya Proporsi antara lebar dan tinggi diekspresikan dalam lima teknik yang disebut dengan santika, paushtika, parshnika/jayada, adbhuta, dan sarvakamika. Setiap teknik mempunyai perbandingan dalam membentuk proporsi. Santika mempunyai arti saat tinggi dari bangunan adalah 21/4 dari lebar bangunan, paushtika adalah saat dimana tinggi bangunan merupakan 2 kali dari lebar bangunan, parshnika/jayada adalah saat tinggi bangunan adalah 13/4 dari lebar bangunan, adbhuta adalah saat tinggi bangunan adalah 11/2 dari lebar bangunan dan sarvakamika adalah saat tinggi bangunan adalah $11 / 4$ dari lebar bangunan [6].

\section{METODE PENELITIAN}

Dalam melakukan penafsiran bentuk Candi Padang Roco Peneliti ini menggunakan pendekatan penelitian kualitatif didalam memperoleh data dilapangan. dan literatur sebagai pedoman yang bukan menjadi pijakan utama. Selain itu penelitian ini menggunakan metode field research atau penelitian lapangan. Pendekatan field research dipilih karena pendekatan ini lebih cenderung kepada pengamatan mendalam di lapangan terhadap sebuah objek mengingat penelitian ini berkaitan dengan bentuk dan ukuran detail , sehingga perlu adanya pengukuran langsung dimensi obyek di lapangan. Data primer akan lebih mudah dikumpulkan dengan pengukuran pada obyek candi-candi di Padang Roco. Permasalahan dan pertanyaan terhadap sebuah objek akan mudah ditemukan dengan observasi langsung dilapangan.

Survei dan Pengumpulan Data, Kegiatan ini dimaksudkan untuk mencari data dan informasi yang diperlukan dalam proses analisis. Data-data yang dikumpulkan meliputi pengumpulan data primer (survey dan pengukuran) serta pengumpulan data 
sekunder. Persiapan Kegiatan, Sebelum kegiatan pengumpulan data dilakukan koordinasi guna persiapan dan mobilisasi personil dalam hal ini mahasiswa dan tukang untuk melakukan pengukuran. Termasuk melakukan kajian teoritis mengenai proporsi pada arsitektur candi. Serta melakukan pendataan awal kasus-kasus yang dijadikan objek penelitian. Menyiapkan perlengkapan yang digunakan untuk survey terutama peralatan pengukuran dan dokumentasi . juga menyiapkan tabel survei sehingga memudahkan didalam memindahkan data.

Survei lapangan dilakukan untuk mengetahui kondisi eksisting di setiap kasus, antara lain: Bentuk tapak dan posisi bangunan didalam Tapak terkait ukuran, jarak dan orientasi bangunan, Bentuk tapak dan posisi bangunan didalam Tapak terkait ukuran jarak dan orientasi bangunan, Bentuk denah, tampak dan potongan melintang eksisting candi., Menggambar detail ragam hias dan ornamen yang terdapat pada candi maupun reruntuhan artefak ornament candi baik itu disekitar bangunan candi maupun museum serta mengetahui bahan yang digunakan, Melakukan wawancara terhadap tokoh yang mengetahui sejarah candi terkait informasi fisik maupun non fisik, Mempelajari bagian kaki, badan dan kepala candi serta mencari ukuran detail dengan tujuan perbandingan angka antar segmen.

\section{Pengumpulan Data Sekunder}

Melakukan pengumpulan data sekunder dan informasi lain yang akan digunakan sebagai referensi pelaksanaan kegiatan, antara lain: Mencari data mutahir Balai Arkeologi mengenai Arsitektur Candi, Data inventaris gambar dan penelitian yang pernah dilakukan yang disimpan oleh pemerintah setempat, Menelusuri foto-foto yang tersimpan mengenai candi Muaro Takus, hal ini selain mengetahui bentuk sebelum dipugar juga mungkin kondisi saat itu masih lebih baik dibandingkan saat ini.

Identifikasi bentuk kasus/sample Penelitian, Bentuk tata lay-out denah terhadap tapak, mencari orientasi bangunan terhadap arah mata angin, jalan maupun sungai, Identifikasi tata ruang meliputi tata ruang berkaitan zonasi fungsi, pola hubungan ruang, hierarki ruang dan bentuk ruang. Identifikasi morfologis meliputi ; bagian dasar bangunan, bagian dinding bangunan dan bagian atap candi, Identifikasi ukuran dan dimensi bangunan candi.
Perumusan Analisis dan Konsep Bentuk Candi; Gambar hasil Identifikasi akan dikaji secara rinci khususnya ukuran terkait proporsi dan dikaitkan dengan proporsi kajian relief candi Borobudur dan pedoman manasara Silpasastra, Hasil temuan bentuk akan dikelompokan dan dirumuskan persamaan dan perbedaan konseptual proporsi Candi Bumiayu, Muaro jambi Candi Muaro, Candi Muaro Takus dan Candi di Jawa (kajian Atmadi) dan buku manasara Silpasastra. Merumuskan hasil persamaan dan perbedaan kedalam penyusunan kembali reruntuhan dan prediksi perletakan ornament serta reruntuhan candi sehingga menghasilkan tam pilan Candi secara utuh.

\section{Lokasi dan Kasus Penelitian}

Lokasi penelitian adalah Candi Padang Roco Sumatera Barat Situs Candi Padang Roco terletak di Jorong Sungai Langsek, Kenagarian Siguntur, Kecamatan Sitiung, Kabupaten Dharmasraya. Secara geografis situs ini terletak pada sebuah dataran pada ketinggian sekitar $160 \mathrm{mdpl}$ dan terletak pada posisi $1^{\circ}$ LS dan $109^{\circ} 44^{\prime} \mathrm{BT}$.

\section{HASIL DAN PEMBAHASAN}

\section{Rekonstruksi Bentuk Candi 01 Padang \\ Roco}

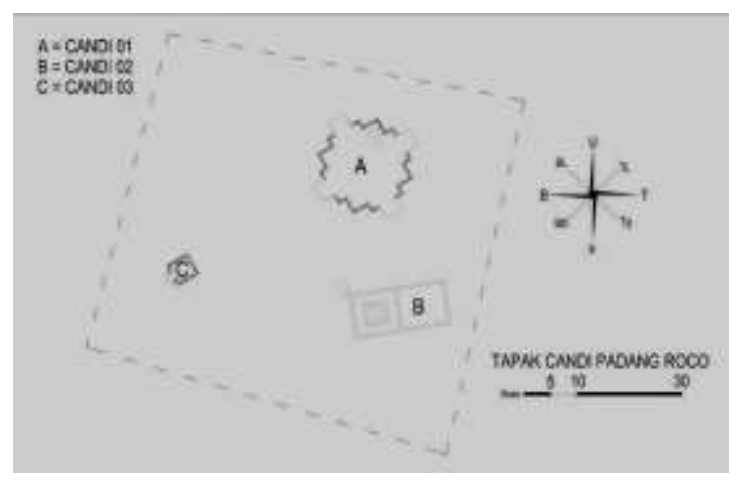

Gambar 2. Tata Spasial Candi Padang Roco (Sumber : Dokumentasi Pribadi, 2018)

Candi I merupakan candi induk yang memiliki ukuran paling besar dibanding candi lainnya di situs Padang Roco. Bentuk dasar denah Candi I berbentuk persegi dengan empat arah orientasi atau memiliki empat akses tangga. Bentuk denah candi seperti ini sangat jarang ditemukan pada Candi di Jawa hanya beberapa candi di Jawa yang memiliki bentuk 
Tipe denah seperti ini yaitu Candi Batujaya, candi Induk situs Candi Sewu di Jawa Tengah. Adapun bentuk denah dengan empat orientasi bangunan umumnya dimiliki oleh peninggalan candi Budha yang berukuran besar seperti Candi Borobudur dan candi Budha di Indocina. Di Sumatera tipe denah Candi seperti ini hanya terdapat pada Candi Bumiayu yaitu Candi 01 dan candi 03. dimana dari bentuk kaki candi terlihat penjorokan empat sisi yang mencerminkan orientasi atau akses tangga menuju candi, akan tetapi uniknya pada kasus candi ini bentuk denah tidak simetris seperti candi Budha lainnya melainkan ada penjorokan teras pada sisi timur. Sedangkan bentuk orientasi 4 sisi pada candi Lorojonggrang memiliki dimensi hampir sama tidak memiliki penjorokan keluar melainkan memiliki bentuk simetris.

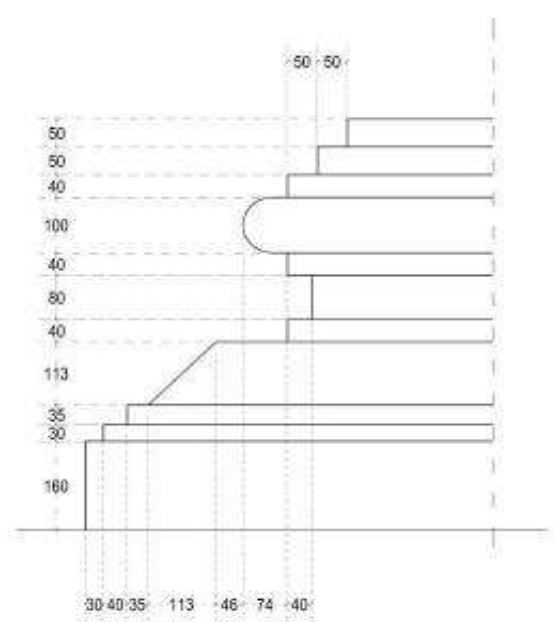

Gambar 2. Bentuk Eksisting kaki Candi 01 (Sumber : Dokumentasi Pribadi, 2018)

Karakter kaki candi Sumatera umumnya memiliki bentuk yang simetris antara Panil atas dan panil bawah. Dengan menganalisis beberapa bentuk kaki candi khususnya di Sumatera tampak jelas bahwa kaki candi 1 Padang Roco memiliki kesamaan dengan beberapa candi di Sumatera . didalam melakukan pendekatan peneliti membuat analisis perbandingan proporsi di beberapa bangunan candi di Sumatera, dikarenakan pada bagian bawah candi pada kasus candi Padang Roco memberikan gambaran yang jelas bentuk ukuran dan proporsinya sehingga didalam kasus menentukan bentuk kaki candi peneliti hanya berfokus pada bagian tengah kaki candi atau bagian panil.

Pada kasus candi tinggi di Muaro jambi bagian bawah tapak candi sebelum bagian profil tengah memiliki ukuran yang sangat jauh dibanding bagian atasnya sedangkan pada kasus bagian lainnya sudah mendekati sehingga penentuan proporsi pembagi bagian tersebut tidak dimasukan perhitungan. Adapun candi yang dijadikan referensi adalah candi yang ada di sumatera dan memiliki bagian kaki secara utuh.

Candi di Sumatera umumnya memiliki angka perbandingan yang besar pada bagian tengah hal ini berbanding terbalik dengan semua kasus didalam candi bahal dimana umumnya justru memiliki ukuran yang terkecil pada sisi bagian tengah candi meskipun pada candi utama Bahal I memiliki kesamaan angka dengan kasus Muaro jambi dan Muarotakus. Didalam menentukan angka proporsi peneliti merujuk kepada candi Muaro Jambi, Muarotakus dan Candi Bahal I. merujuk pada Muaro Jambi hal ini dikarenakan keberadaan candi Padang Roco sama sama bermuara ke sungai batang hari Jambi sehingga besar kemungkinan mereka memiliki kedekatan dalam langgam arsitektural dan pengaruh budaya. Sedangkan dari morfologi arsitrap atau profil menerus memiliki kedekatan bentuk dengan candi Muarotakus selain itu melihat pada sisi atas sisa candi didapatkan petunjuk candi ini memiliki pondasi lapis kedua yang menunjukan keberadaan dua podium pembentuk kaki candi hal ini disebabkan pondasi tidak begitu lebar sehingga tidak memungkinkan berfungsi sebagai pembentuk badan candi. Melihat angka rata rata proporsi umumnya perbandingan antara bagian bawah dinding kaki candi dan bagian tengah memiliki perbandingan $1: 1,4: 1$ (lihat gambar 3 ). sehingga peneliti menganggap perbandingan sudah mendekati dan kalaupun terjadi perbedaan selisihnya akan sangat kecil, sehingga peneliti memiliki keyakinan akan perbandingan proporsi tersebut hal ini didasari oleh hasil rekonstruksi terakhir meninggalkan

Melihat perhitungan kaki candi utama padang roco dapat dilihat hanya menyisakan bagian dasar candi dan menyisakan setengah profil hak ini dikarekana rekonstruksi memiliki sedikit sekali petunjuk . mempelajari morfologi candi pada umumnya maka bagian kaki ini masih memiliki bentuk setengah pada bagian atas 
candi . sisa kaki candi saat ini meyisakan ketinggian sekitar 7,38 $\mathrm{m}$ dari muka tanah dengan mencoba merujuk pada angka perbandingan 1: 1.4: 1 maka berdasarkan perhitungan maka total ketinggian kaki candi adalah sekitar $1.59 \mathrm{~m}$ dari permukaan tanah.

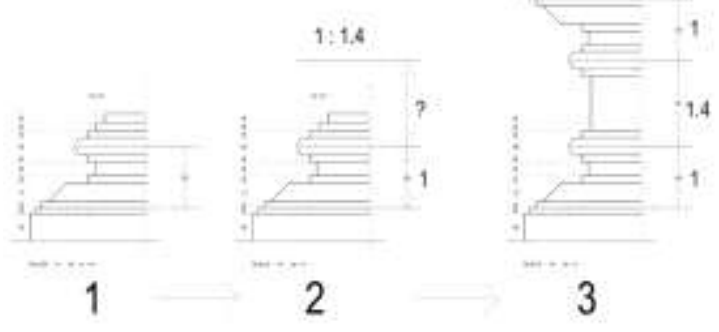

Gambar 3. Tafsiran Bentuk Utuh Kaki Candi 01 (Sumber : Dokumentasi Pribadi, 2018)

Berdasarkan hasil pengukuran lapangan dapat dipastikan bahwa candi 1 memiliki lapis podium kedua hal ini dilihat adanya pondasi pada lapisan dalam candi. Konsep candi ini memiliki kesamaan dengan candi Bumiayu dan Muaro jambi dimana candi memiliki pondasi menerus yang pada bagian tengahnya diisi gravel dan tanah berbeda dengan candi Bahal Padang Lawas dimana semua bagian solid berbahan batu bata hal ini kemungkinan karena candi tidak terlalu lebar denahnya Berdasarkan pengamatan pondasi candi Padang Roco memiliki lapisan beberapa dinding pondasi serupa dengan Candi 01 Bumiayu, Candi 03 Bumiayu, dan Candi Tankidat Padang Lawas.

Candi 01 Padang Roco memiliki empat arah orientasi seperti karakter candi di Indo Cina yang umumnya membentuk candi berupa Punden Berundak dengan empat sisi simetris dimana secara sekilas menyerupai tipe Candi Borobudur. Tipe orientasi candi seperti ini memiliki kesamaan dengan candi tipe menara di Jawa Tengah seperti Candi lorojongrang dimana juga terdapat empat sisi tangga akan tetapi candi berupa menara yang lebih tinggi dari lebar bangunan berbeda dengan tipe punden berundak. Dengan melihat konstruksi candi yang hanya menggunakan batu bata dan lebar pondasi lapis dalam candi yang tidak begitu lebar kecil kemungkinan berupa candi menara selain itu denah bangunan sangat lebar sehingga apabila berupa candi menara maka ketinggian candi bisa mencapai $20 \mathrm{~m}$ hal ini apabila benar maka hasil kajian arkeolog didalam merekonstruksi kaki candi sangat dipertanyakan dimana pertanyaan dasar kemana sisa reruntuhan candi yang begitu banyak sebagai pembentuk bangunan. Lain halnya apabila candi berupa tipe podium dan banyak menggunakan gravel atau tanah sebagai pengisi bagian dalam Candi. Candi Sumatera yang menunjukan pondasi candi dengan cukup jelas ada di Situs Candi Bumiayu dan Padang Roco.

Candi 01 Padang Roco memiliki tipe struktur yang sama dengan Candi di Bumiayu dimana terdapat isian gravel diantara dinding candi yang membentuk beberapa lapis podium. Pada kasus candi bumiayu khususnya Candi 01 melihat dari lapisan pondasi setidaknya candi ini memiliki tiga tingkat podium atau undakan sedangkan Candi 08 dalam situs Bumiayu juga memiliki 4 undakan podium umumnya lima termasuk kepala candi pada bagian tengah. Undakan candi umumnya berangka ganjil termasuk stupa diatasnya. Bentuk candi berundak umumnya hanya dua undakan saja sebagai kaki candi sedangkan undakan lebih dari 2 kaki umumnya memiliki bentuk dinding kaki yang polos hal ini dapat dilihat pada Candi Tinggi Muaro Jambi, Candi Bakong Angkor Indo Cina, Candi Baksei Chamkrong Angkor. Dan beberapa candi Angkor lainnya umumnya membentuk undakan lebih dari dua undakan. Akan tetapi umumnya memiliki profil polos berbeda dengan kasus candi muaro takus yaitu Candi Tuo dimana memiliki tiga lapis podium dengan dinding memiliki pola profil yang serupa dengan Candi 01 Padang Roco dengan ini peneliti memiliki dugaan dari segi bentuk dan gaya memiliki bentuk yang hampir serupa dengan Candi Tuo Muaro Takus.

Melihat denah Candi Angkor abad ke 9 nampak jelas memiliki konsep berundak dimana memiliki angka tahun yang sama dengan candi Borobudur akan tetapi di Indo Cina kompleks percandian lebih kompleks lagi dan terkadang berbeda dengan candi di Indonesia dimana terlihat sekali pada gaya 
Candi di Indo Cina selain melebar seperti ciri Candi Budha juga terdapat candi bergaya menara diatas undakan tersebut dimana candi meninggi ini umumnya menjadi ciri Candi bergaya Hindu tetapi penulis disini tidak berpegang teguh bahwa Candi budha cenderung melebar karena bisa saja candi yang membentuk menara dan langsing bergaya Budha seperti Candi Mahligai di Situs Candi Muaro takus. Didalam kompleks Candi Bakhng dan Bakheng memiliki pola yang sama dengan Candi di Jawa Tengah hal ini tidak mengherankan karena menurut Groslier Raja Jayavarman II terkait berdirinya Angkor pernah hidup di Jawa terkait sejarah Tchenla berpindah ke Jawa dan mengembangkan dinasti Syailendra yang kuat, sehingga Jayavarman memiliki keterkaitan yang kuat dengan Jawa pada abad ke 8 [7].
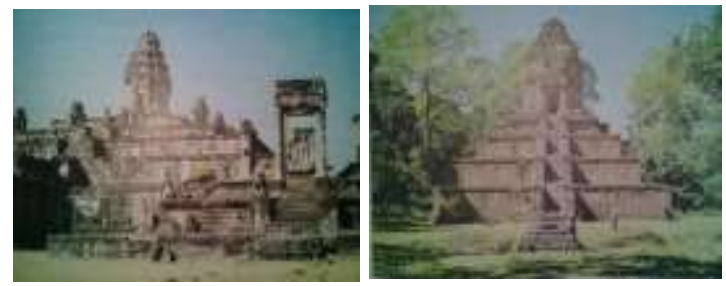

Gambar 4. Gambar Candi Bakhong (kiri) dan Baksei Chamkrong (kanan) (Sumber : Groslier, 2017)

Selain Candi Borobudur dan Candi lainnya di Jawa tengah candi dengan empat orientasi juga ditemukan di Jawa Barat yaitu Candi Batu jaya yang juga memiliki aliran Gaya Candi Budha terlihat jelas pada sisa bentuk Kaki Candi memiliki empat akses Tangga masing masing berorientasi ke Tenggara, Timur Laut, Barat Daya dan Barat Laut serupa dengan orientasi Candi 01 Padang Roco. Akan tetapi berdasarkan kajian yang dilakukan Prajudi, candi batujaya memiliki bentuk berupa percandian kayu dimana tergolong dalam tipe kaki batu, dinding batu dan atap kayu yang menyerupai pendopo yang dikelilingi dinding batu [8].

Candi berbahan bata di Sumatera lainnya yang berundak adalah Candi Tinggi di Muaro jambi akan tetapi pada candi ini memiliki perbedaan gaya profil dinding kaki Candi dimana pada bagian dasar sangat polos tanpa profil lengkung seperti kaki Candi Padang
Roco sehingga kecil kemungkinan kedua candi memiliki tipe bentuk yang sama. Dalam kasus ini peneliti lebih memilih Candi Tuo Muaro Takus dan Candi bakhong dan Bakhsei Indo Cina sebagai referensi di dalam merekonstruksi bentuk Candi karena selain memiliki kesamaan bahan juga bentuk dan tipe candi memiliki kesamaan mulai dari ukuran podium yang cenderung melebar dan memilik banyak akses tangga yang tidak hanya satu juga miliki profil dinidng kaki yang sama. .

Candi 1 merupakan candi yang berbahan batu bata dan antara dinding kaki candi diisi tanah dan bahan bebatuan krikil melihat ukuran candi hampir sama dengan Candi 1 bumiayu sehingga berdasarkan pengamatan jarak antar pondasi setidaknya candi 1 Padang Roco memiliki tiga tingkat podium candi tetapi pada bagian tengah candi sudah tertutup bata sehingga tidak terdapat petunjuk apakah berisi batu bata penuh atau hanya tanah seperti halnya Candi 1 Bumiayu. Akan tetapi dengan melihat sisa pondasi Candi 02 dan melihat pondasi Candi Bahal di dan Tandikat di Padang Lawas memiliki konstruksi batu bata secara utuh tanpa isian gravel pada bagian tengah. Sehingga besar kemungkinan pada bagian tengah candi memiliki pondasi utuh sama halnya dengan sisa pondasi pada Candi 2 Padang Roco.

Dari gambar 4 dapat dilihat perkiraan jumlah podium Candi tersebut adalah 4 podium dengan tambahan satu stupa atau puncak candi sehingga keseluruhan memiliki lima tingkatan karena umumnya Candi dengan tipologi tersebut memiliki jumlah yang ganjil. Didalam lokasi situs ditemukan prasasti Padang Roco dimana prasasti tersebut merupakan tulisan yang berada di alas Arca Amogaphasa sebagai pemberian dari dari śrī mahārājādhirāja keṛanagara wikrama dharmmottunggadewa raja dari kerajaan Singasari di Jawa untuk rakyat dan Raja Kerajaan Melayu Dharmasraya di Sumatera. Dari prasasti tersebut memang dapat disimpulkan ada hubungan antara Raja Jawa dan Sumatera akan tetapi terlalu cepat apabila mengaitkan keberadaan Arca tersebut dengan Candi padang Roco karena belum jelas posisi hubungan antara kedua Raja tersebut apakah 
rekan dagang atau persekutuan karena pada abad tersebut hegemoni Sriwijaya belum semuanya hilang, selain itu dharmasraya juga menjadi bagian dari kekuasaan Sriwijaya. Sehingga didalam penelitian ini peneliti hanya berfokus pada aspek arsitektural yaitu bentuk tipomorfolog Candi terkait Candi lainnya di Sumatera dengan juga melihat keterkaitan secara tidak langsung dengan Candi di Jawa dan Indo Cina. Keberadaan candi Padang Roco bisa saja sudah berdiri sebelum datangnya Prasasti karena umumnya apabila prasasti tersebut berbarengan dengan pembangunan candi maka setidaknya berada didalam ruang candi dan menjadi kesatuan tertimbun didalam reruntuhan karena berdasarkan informasi Arca ditemukan disekitar lingkungan candi.

Melihat bentuk dan jumlah pondasi kaki candi padang roco yaitu Candi 01 memiliki jumlah podium paling banyak dimana umumnya Candi di Sumatera hanya memiliki 3 podium. Dalam kasus ini setidaknya besar kemungkinan candi ini memiliki empat podium dan tambahan 1 podium kecil sebelum badan dan kepala candi berdiri. Gaya candi yang ditopang oleh podium berlapis umumnya hanya berada di Indo Cina sedangkan di Sumatera seperti Candi Tuo di Muaro Takus bisa dikatakan Candi ini tidak memiliki Badan Candi melainkan hanya berupa Stupa yang ditopang oleh Punden Berundak sedangkan dalam kasus Batujaya hampir sama dengan Candi Angkor yaitu Candi yang ditopang oleh Podium akan tetapi bedanya di kasus Batu jaya podiumnya tidak bertingkat banyak melainkan hanya 1 dan 2 undakan saja.

Sehingga dalam kasus Candi 01 Padang Roco peneliti cenderung tipe Candi menyerupai Candi Padang Lawas untuk bentuk Podium sedangkan Candi utama pada bagian puncak berupa Candi berbentuk menara seperti di Angkor hal ini juga dikuatkan dengan bentuk Candi Batujaya dimana menyisakan badan candi persegi empat dengan empat orientasi berupa relung menyerupai pintu Candi. Untuk bentuk candi pada bagian atas podium peneliti lebih mengarah pada Candi Bahal Padang Lawas hal ini dikarenakan Candi Bahal merupakan candi disumatera yang paling lengkap bentuknya dibanding candi lainnya di Sumatera, selain itu secara geografis kedua lokasi ini relatif masih berada tidak jauh sehingga pertukaran informasi dan budaya sangat mungkin terjadi.

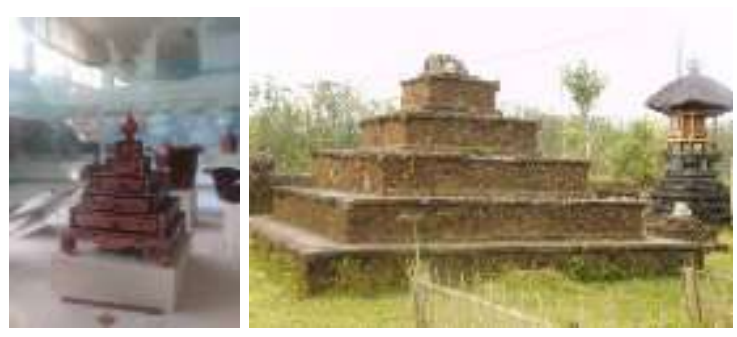

Gambar 5. Botekan, lemari kecil tempat menyimpan aksesoris di Palembang (kiri) Struktur Berbentuk Punden (kanan) (Sumber : Dokumentasi Pribadi, 2017)

Bentuk bangunan bertingkat yang menyerupai punden banyak ditemukan di Sumatera Bagian Selatan bahkan perabot yang digunakan oleh masyarakat Palembang dan sekitarnya bentuknya pun menyerupai susunan punden berundak hal ini menguatkan bahwa bentuk punden berundak sudah sangat akrab dalam kehidupan budaya masyarakat di Sumatera pada umumnya. selain itu petunjuk penting dari perabot tersebut adalah terdapatnya kuncup bunga teratai pada bagian puncak nya, hal ini menjelaskan masih ada pengaruh budhisme pada seni perabot tersebut. Analogi antara perabot dan bangunan candi adalah hal yang sangat mungkin terjadi karena dunia desain memikiki cakupan yang luas dan umumnya saling bersinergi satu sama lainnya terkait tren, langgam atau tuntutan budaya tertentu.

Melihat proporsi perbandingan ketinggian antar podium candi khususnya candi yang memiliki 3 tingkat podium umumnya podium 1 dan 2 tidak memiliki angka yang berjauhan bahkan cenderung sama sedangkan pada trap ketika angka perbandingan berkurang secara signifikan $25 \%$ sampai $50 \%$ dari podium kedua sedangkan dari podium 1 ke 2 reatif sama hanya berkisar $5 \%$ saja. Melihat tipe podium candi Angkor dan Muaro takus besar kemungkinan Candi Padang Roco memiliki kesamaan dimana podium 1 sampai podium 3 memiliki ukuran yang hampir sama sedangkan 
penurunan proporsi terjadi pada podium keempat saja dengan kecendrungan penurunan sekitar $30 \%$. Dengan demikian peneliti mengambil angka perbandingan Candi Tuo dimana setidaknya berdasarkan deret proporsi didapatkan perbandingan $1,3: 1,24$ : $1,18: 0,88$ atau dibulatkan menjadi $1,42: 1,36$ : 1,30 : 1 masing masing mewakili Podium 1, Podium 2, Podium 3 dan Podium ke empat. Kajian ini sesungguhnya hanya bersifat penafsiran akan tetapi pendekatan yang dilakukan sudah cukup rinci dan melalui proses analogi yang panjang dan pada setiap keputusan melihat keterkaitan bentuk antar Candi di Sumatera, Jawa dan Indo Cina.

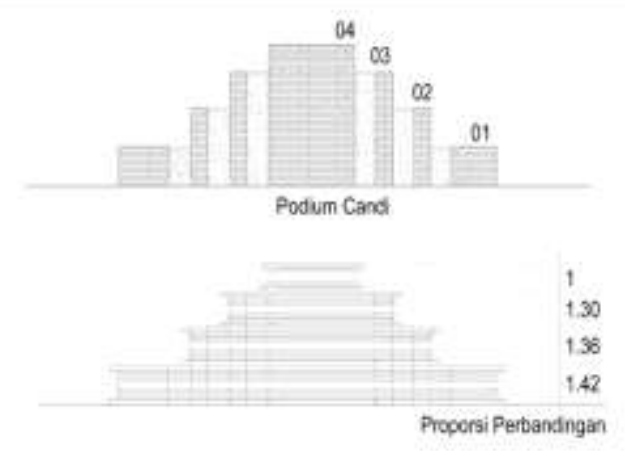

Gambar 6. Tafsiran Bentuk Podium Candi 01

(Sumber : Dokumentasi Pribadi, 2018)

Berdasarkan hasil tafsiran bentuk undakan candi candi ini memiliki bentuk menyerupai candi Tuo dan Candi di Angkor Indo Cina hal ini sangat memungkinkan karena gaya arsitektur ini berkembang pada masanya yaitu adab ke 8 hal ini membuka kemungkinan keberadaan candi di Sumatera bisa saja memiliki masa yang sama dengan Candi Indo Cina akan tetapi arkeolog di Indonesia berteori hampir semua Candi di Sumatera dibangun diatas abad ke 10 padahal melihat gaya profil dan langgam candi memiliki tipe gaya candi masa klasik tua. Penanggalan ini umumnya selain dilakukan carbon dating juga penafsiran atas temuan temuan di sekitar candi seperti arca dan prasasti, akan tetapi arca dan prasasti tidak menjamin usia sebuah candi karena bisa saja elemen tersebut adalah elemen tambahan sama hal nya keberadaan mihrab pada sebuah masjid apabila sudah rusak maka akan diganti yang baru. Untuk itu peneliti tidak terlalu fokus didalam menafsirkan usia candi melainkan hanya berpegang teguh dalam aspek morfologis candi terkait langgam dan gaya candi. Penafsiran selanjutnya adalah bagaimana bentuk stupa candi pada bagian puncak hal ini sangat penting dilakukan karena juga terkait dengan langgam candi. Melihat Tipe puncak candi Bakhong Ankor memiliki kesamaan dengan bagian puncak candi Bahal di padang Lawas sehingga dalam hal ini peneliti mengacu bentuk candi bahal didalam merekonstruksi bentuk bagian puncak Candi 01 Padang Roco. Keberadaan candi puncak padang roco didapatkan dengan melihat keberadaan pondasi padat pada bagian tengah candi yang berdasarkan petunjuk pada proses rekonstruksi Candi Tandikiat I di Situs Padang Lawas bahwa konstruksi batu bata ini mampu mencapai ketinggian hamper $10 \mathrm{~m}$ sehingga sangat memungkinkan candi ini memiliki struktur puncak yang tinggi.

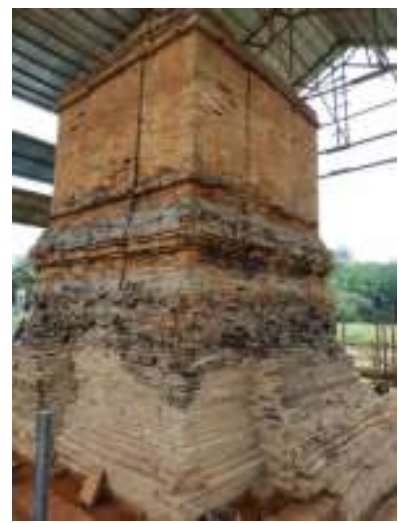
Gambar 7. Foto Rekonstruksi Candi Tandikat I
Padang Lawas

(Sumber : Dokumentasi Pribadi, 2018)

Bentuk ukuran pondasi pada bagian pusat candi 01 Padang Roco memiliki ukuran yang hampir sama dengan bagian tengah candi Bahal dan Tandikat di Padang Lawas akan tetapi memiliki ukuran yang sedikit lebih kecil yang membedakan dari bentuk kedua candi adalah orientasi dan fasad Candi. Dalam kasus Candi 01 Padang Roco memiliki empat ambang pintu Candi sedangkan pada kasus Candi Padang Lawas hanya memiliki satu buah pintu kearah Tenggara. Candi Padang Lawas yang paling sempurna bentuknya hingga ke bagian puncak adalah candi Bahal I dengan perbandingan lebar pondasi dan total ketinggian mulai dari permukaan tanah sekitar 
1: 3 sedangkan ketinggian dari podium teratas ke bagian puncak 1: 2 ratio ini menjadi acuan peneliti dalam rekonstruksi bagian puncak candi karena memiliki kedekatan wilayah juga memiliki kemungkinan kesamaan bentuk.

Selain rekonstruksi bentuk bagian puncak candi bentuk dan ukuran tangga juga menjadi perhatian penting, apabila merujuk pada candi Angkor di Indo Cina tangga dari podium 1 sampai 4 memiliki lebar yang sama akan tetapi didalam kasus Candi 01 tidak memungkinkan apabila tangga memiliki lebar yang sama karena tangga pada podium pertama sangat lebar bahkan sedikit lebih lebar dari pondasi bagian puncak candi sehingga yang paling memungkinkan poroporsi lebar tangga sama dengan candi di Sumatera Pada umumnya dimana semakin keatas tangga semakin mengecil. Untuk mendapatkan kompilasi perbandingan data maka peneliti akan membuat skala perbandingan lebar tangga candi antar podium dalam kasus candi Sumatera data tersebut menjadi dasar bagi peneliti didalam menentukan tafsiran lebar tangga antar podium candi. Dalam hal ini peneliti memiliki dasar yang kuat dalam asumsi lebar tangga yaitu keberadaan pondasi tangga pada podium pertama candi 1 dan mencari prediksi lebar tangga pada puncak candi, hasil temuan ukuran pada bagian puncak dan bagian dasar menjadi titik acuan pembagi lebar tangga pada podium diantaranya.

Berdasarkan data dapat dilihat terjadi pengurangan angka podium semakin kebagian puncak meskipun sedikit petunjuk candi yang memiliki lebih dari dua tingkat tangga tetapi peneliti memiliki dasar didalam menentukan ukuran tangga yang mengecil semakin menuju podium teratas, data ini belum cukup bagi peneliti di dalam menentukan ukuran sehingga peneliti perlu mencari perbandingan proporsi lebar candi bagian puncak terhadap lebar tangga sehingga capaian pengunci ukuran bagian dasar dan teratas ditemukan dalam hal ini petunjuk yang terukur peneliti memilih Candi Bahal di padang lawas sebagai perbandingan proporsi lebar tangga bagian atas. Pada candi Bahal I perbandingan lebar candi dan lebar tangga sekitar $1: 1,73$ angka perbandingan lebar badan bangunan adalah dinding candi diluar bentuk relief profil candi. Perbandingan selanjutnya adalah candi Bahal II yaitu 1 : 2,1 sedangkan candi Bahal III memiliki perbandingan lebar badan candid an bagian tangga sebesar $1: 2,4$ apabila dilihat angka rata rata maka perbandingan lebar tangga dan badan bangunan pada badan candi bagian puncak podium adalah $1: 2$.

Angka perbandingan tersebit akan dijadikan peneliti didalam menafsirkan ukuran lebar tangga bagian puncak podium Candi 01 Padang Roco. Ukuran dinding pada puncak candi 01 berdasarkan analisis pondasi sekitar $3,5 \mathrm{~m}$ persegi sehingga apabila mencari proporsi lebar tangga dengan ukuran proporsi rata-rata candi bahal sekitar $1,75 \mathrm{~m}$. amgka ini menjadi pengunci dari lebar tangga antar podium. Untuk menguji apakah lebar ytangga ini sesuai proporsinya peneliti mencoba mengalikan angka proporsi candi Bahal 1 terhadap padang Roco diketahui angka perbandingan Candi Bahal I podium 1,2 dan 3 adalah $1.95: 1.1: 1$ sehingga angka tangga paling dasar candi 01 adalah 3,4 $\mathrm{m}$ angka ini sungguh sangat mendekati karena ukuran asli tangga podium 1 dilapangan sekitar $3,5 \mathrm{~m}$ hanya selisih $10 \mathrm{~cm}$. sehingga perbandingan candi Bahal bisa digunakan didalam mencari lebar tangga podium 2 dan 3 dimana podium 2 perbandingannya menjadi 1.1 sedangkan podium ketiga diantara 1.1 dan 1 karena proporsi 1 sudah didapat pada angka 1,75 m, dalam hal ini peneliti mencoba mencari selisih deret angka dimana peneliti akan mengurangi 0.1 pada podium atas sehingga perbandingannya secara umum menjadi 2,05 : $1,2: 1,1: 1$. Dengan angka perbandingan ini maka lebar pondasi podium 01 ditemukan angka yang persis yaitu 3,50 berbeda dengan angka sebelumnya. Dari perbandingan diatas didapat lebar tangga masing masing podium Candi 01 Padang Roco yaitu : podium 1 memiliki lebar 3,50 m, podium 2 memiliki lebar 2,1 $\mathrm{m}$, podium ketiga $1,92 \mathrm{~m}$ dan pada bagian puncak memiliki lebar $1,75 \mathrm{~m}$. setelah didapatkan angka ukuran lebar tangga pada masing masing podium selanjutnya adalah mencari perbandingan lebar anak tangga dan 
lebar dinding pembatas tangga sisi kiri dan kanan candi. Untuk ini peneliti menggunakan metode yang sama yaitu mencari perbandingan lebar tangga dan dinding tangga akan tetapi dalam hal ini peneliti hanya memilih candi utama dan memiliki podium bertingkat .

Berdasarkan data yang dirangkum, proporsi lebar tangga dan dinding tangga cukup bervariasi angka dinding tangga yang memiliki ukuran besar dimiliki oleh Candi Tinggi di Bumiayu dan Candi Bahal III di Padang Lawas bentuk perbandingan ini tidak sesuai apabila diterapkan pada Candi 01 karena lebar tangga pada podium atas tidak memiliki bidang yang cukup Lebar, berdasarkan angka tabel perbandingan yang paling memungkinkan antara lebar anak tangga dan lebar tangga keseluruhan berkisar 1: 1,5 sampai $1: 2$, melihat kasus percandian di Indocina khususnya Candi Bakheng dan Indo Cina perbandingan lebar dan anak tangga adalah berkisar 1: 1 sehingga besar kemungkinan padang roco memiliki lebar dinding tingga relative kecil yaitu berkisar $1: 1,5$.

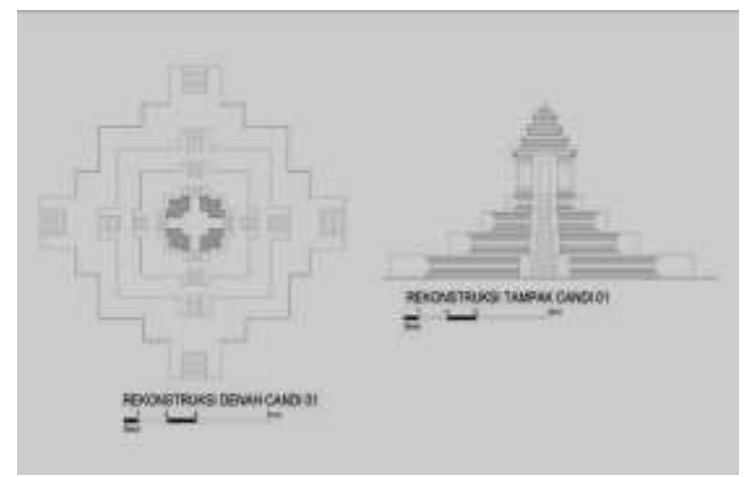

Gambar 8. Hasil Rekonstruksi Candi 01 Padang Roco

(Sumber : Dokumentasi Pribadi, 2018)

Dalam kajian ini teori proporsi candi tidak terlalu menjadi acuan akan tetapi perlu dilakukan perbandingan secara umum hal ini diperlukan agar proses pencarian bentuk benar-benar berdasarkan fakta dilapangan karena penelitian ini bersifat penelitian lapangan maka hasil akhir baru dilakukan perbandingan dengan teori proporsi candi secara umum. Selain itu metode ini diharapkan mampu membuka kemungkinan baru angka proporsi yang menciptakan langgam candi
Sumatera. Secara keseluruhan perbandingan lebar dan tinggi candi adalah 1,3:1 termasuk kaki candi dimana berdasarkan panduan silpashastra umumnya bangunan candi memiliki angka lebar yang lebih besar daripada dimensi tinggi bangunan, proporsi lebar dan tinggi bangunan pada bagian inti candi atau bangunan puncak candi yang membentuk stupa 1:1,7 dimana menurut Acharya, angka perbandingan ini tergolong proporsi Parshnika atau Jayada [6].

Penarikan angka proporsi lebih bisa dikaitkan dengan acuan candi apabila hanya mengambil bangunan pucak candi sedangkan apabila semua podium dimasukan dalam angka perbandingan maka akan menghasilkan angka yang berbeda. Berdasarkan kajian terhadap candi Muaro takus angka perbandinganya memiliki kesamaan dengan Candi Padang Roco dimana pada perbandingan lebar dan tinggi candi memiliki karakter lebih melebar dibandingkan vertikal yaitu berkisar 3:1.

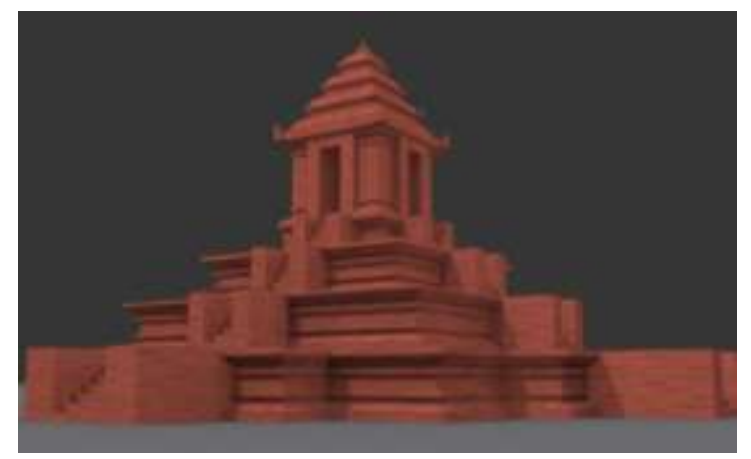

Gambar 9. Bentuk 3 Dimensi Hasil Rekonstruksi Candi 01 Padang Roco

(Sumber : Dokumentasi Pribadi, 2018)

Dengan melihat gambar 17 dapat dilihat candi ini memiliki langgam bentuk yang unik dan tidak ditemukan pada candi hasil rekonstruksi di Indonesia pada umumnya dimana pengaruh bentuk memiliki tipologi yang serupa dengan candi Ankor Indo Cina akan tetapi ciri profil candi di Sumatera juga ikut memberikan tampilan langgam gaya Arsitektur Candi ciri Sumatera. Perabot kuno yang ditemukan di Palembang yang memiliki bentuk bertingkat menyerupai punden berundak juga menjadi dasar yang menguatkan bahwa bentuk punden berundak bukanlah merupakan hal yang langka bagi masyarakat di Sumatera pada 
umumnya bahkan rumah adat Palembang yaitu Rumah Limas apabila semua dinding dan atapnya dihilangkan maka lantai bangunan rumah tersebut akan terlihat bertingkat-tingkat menyerupai punden berundak.

\section{KESIMPULAN}

Situs Candi Padang Roco merupakan petunjuk yang penting didalam penyempurnaan perumusan artefak candi pada masa Sriwijaya dimana didalam kajian ini peneliti mengamati percandian di Jawa dan Indo Cina sehingga diharapkan ditemukanya benang merah tpologi Candi di Sumatera. Dalam kasus penelitian Padang Roco ditemukan bentuk Candi yang jarang sekali ditemukan di Indonesia dimana terdapat candi yang berbentuk berudak seperti gaya Ankor di Indocina dan juga ditemukan bangunan yang memiliki bentuk denah dan proporsi yang sangat sama dengan candi di Muaro takus dimana memiliki bentuk memanjang dengan stupa pada satu sisi bangunan, selain itu pada kasus candi 3 memiliki bentuk dan ukuran yang sama dengan candi di Jawa Barat. Berdasarkan tata letak geografis Sumatera merupakan pertemuan dua kebudayaan agama yang sangat besar dimana pada bagian Utara yakni dataran Indocina merupakan basis agama Bidha yang kuat hingga saat ini sedangkan pada sisi Jawa Timur sampai Bali memiliki kebudayaan Hindu yang kuat juga hingga saat ini sehingga Jawa Barat dan Sumatera merupakan wilayah yang berada diantara Budha dan Hindu sehingga tidak heran apabila terjadi pembauran Budaya dan Arsitektur di dalamnya.

\section{DAFTAR PUSTAKA}

[1] Abel, Chris.(1997). Architecture and Identity, Architectural Press, An imprint of Butterworth-Heinemann.

[2] Broadbent, Geoffrey. (1988). Design in Architecture : Architecture and the Human Science, London : David Fulton.

[3] Duerk, Donna P. (1993). Architectural Programming, Van Nostrand reinhold Company, Inc-USA.

[4] Ching, Francis D.K. (1991).Arsitektur : Bentuk Ruang dan Susunanya. Jakarta: Erlangga.
[5] Atmadi, Parmono. (1979). Beberapa Patokan Perancangan Bangunan Candi. Proyek Pelita Borobudur Seri C No 2, hlm 200

[6] Acharya,P.K. (1927). Indian-ArchitectureAccording-to-silpasastra(1).pdf. fisrt edit. ed. P.K. Acharya. London, New York,Bombay, Calcuta, Madra: Oxford University Press.

[7] Groslier, B.P. (2007). Indo Cina Persilangan Kebudayaan. Buku Terjemahan Vol 6. Jakarta : KPG

[8] Prajudi , R.H. (2014). Kajian Tipomorfologi Arsitektur Percandian'Kayu' di Jawa. Bandung : Universitas Parahyangan 
NALARs Jurnal Arsitektur Volume 18 Nomor 2 Juli 2019:105-118 p-ISSN 1412-3266/e-ISSN 2549-6832 